\title{
Movement patterns of loggerhead turtles Caretta caretta in Cuban waters inferred from flipper tag recaptures
}

\author{
F. Moncada ${ }^{1}$, F. A. Abreu-Grobois ${ }^{2}$, D. Bagley ${ }^{3}$, K. A. Bjorndal ${ }^{4}$, A. B. Bolten ${ }^{4}$, \\ J. A. Camiñas ${ }^{5}$, L. Ehrhart ${ }^{3}$, A. Muhlia-Melo ${ }^{6}$, G. Nodarse $^{1}$, B. A. Schroeder ${ }^{7}$, \\ J. Zurita ${ }^{8}$, L. A. Hawkes ${ }^{9, *}$
}
${ }^{1}$ Centro de Investigaciones Pesqueras, Ministerio de la Industria Pesquera, 5ta Ave y 248, Barlovento, Santa Fé, Ciudad Habana, Cuba ${ }^{2}$ Unidad Académica Mazatlán, Instituto de Ciencias del Mar y Limnología, Universidad Nacional Autónoma de México, Apartado Postal 811, Mazatlán, Sinaloa 82000, Mexico
${ }^{3}$ Department of Biology, University of Central Florida, PO Box 162368, Orlando, Florida 32816, USA
${ }^{4}$ Archie Carr Center for Sea Turtle Research, Department of Zoology, PO Box 118525, University of Florida, Gainesville, Florida 32611, USA
${ }^{5}$ FAO-CopeMed II, FAO Fisheries and Aquaculture Department of the United Nations, Subdelegación del Gobierno, Paseo de Sancha 64, Oficina 306, 29071 Málaga, Spain
${ }^{6}$ Centro de Investigaciones Biológicas del Noroeste S. C., Mar Bermejo No. 195, Col. Playa Palo de Sta. Rita, La Paz, BCS 23090, Mexico ${ }^{7}$ NOAA/NMFS Office of Protected Resources, Room 13657, 1315 East-West Highway, Silver Spring, Maryland 20901, USA
${ }^{8}$ CONCENZU, Consultores en Formación, Hermosillo No. 24-104, Col. Roma Sur, Distrito Federal 06760, Mexico ${ }^{9}$ School of Biological Sciences, Brambell Laboratories, Bangor University, Deiniol Road, Bangor, Gwynedd LL57 2 UW, UK

\begin{abstract}
Understanding the spatial movements of threatened marine species, such as sea turtles, is essential as a means of informing appropriate conservation management. Although novel techniques for tracking spatial movements are becoming more widely available (such as satellite tracking), simple techniques such as mark-release-recapture remain effective. A flipper tagging and recovery program in Cuba tagged 210 loggerhead turtles over $14 \mathrm{yr}$ and recovered $7 \%$ of the tags between $2 \mathrm{~d}$ and $3 \mathrm{yr}$ later $($ mean $=296 \mathrm{~d})$. All but one turtle was recaptured in Cuban waters, and data showed limited movement of turtles between northern and southern coasts. A further 50 turtles were recovered that had been tagged in foreign projects, the majority of which were from the USA (but also Mexico, The Bahamas, Canary Islands and Spain). A range of life stages of loggerhead turtles are found in Cuban waters year-round, and given that Cuba has the second largest reef in the Caribbean, it likely provides foraging habitat for significant numbers of loggerhead turtles from at least 6 different countries.
\end{abstract}

KEY WORDS: Movement patterns $\cdot$ Loggerhead turtle $\cdot$ Caretta caretta $\cdot$ Flipper tags · Tag-recapture Cuba $\cdot$ Caribbean

\section{INTRODUCTION}

Assessment of the sizes and trends of animal populations of conservation concern requires life history information to be effective. Sea turtles, all of which are listed by the World Conservation Union as species of conservation concern (IUCN 2008), have cryptic life stages. For example, hatchlings enter the sea nearly immediately after emergence and begin an extended oceanic developmental phase termed the lost years (Carr 1986, Bjorndal et al. 2000, Bolten 2003, Reich et al. 2007), and about which we know very little. The general life history model is probably best understood for western Atlantic loggerhead turtles Caretta caretta (Bolten 2003) which, following the lost years, settle out to coastal areas, generally in the region of their natal 
beach (Hopkins-Murphy et al. 2003, Bowen et al. 2004) and reach sexual maturity several decades later (Casale et al. 2009). Adult females migrate every 2 to $3 \mathrm{yr}$ (Schroeder et al. 2003) to breeding areas, where females lay multiple clutches of approximately 100 eggs on sandy beaches (Schroeder et al. 2003). Despite this established knowledge, specific locations of foraging sites, as well as the migratory routes linking these areas with breeding sites, are not known for many loggerhead turtle populations (Rankin-Baransky et al. 2001, Godley et al. 2008).

Considerable inroads have been made into understanding sea turtle migration using recovery of marked (usually flipper-tagged) individuals (Bell \& Richardson 1978, Meylan et al. 1983, Limpus et al. 1992, Troëng et al. 2005, Moncada et al. 2006, Zbinden et al. 2007, Revelles et al. 2008), inferential techniques such as stable isotopes (Hatase et al. 2002, Reich et al. 2007) and genetic techniques (Bolten et al. 1998, Bowen et al. 2005, Bowen \& Karl 2007) and, increasingly, satellite tracking (reviewed in Godley et al. 2008). Caribbean countries host relatively few major nesting beaches for loggerhead turtles $(<5 \%$ of total Atlantic ocean nesting; Ehrhart et al. 2003) and these are concentrated in the northern extremes of the region (the Bahamas, Cuba, Mexico; Dow et al. 2007). Almost nothing is known of the home ranges, developmental habitats or post-nesting movements of loggerhead turtles from Caribbean nesting beaches (but see Blumenthal et al. 2006). In addition, recent work with loggerhead turtles in the USA (McClellan \& Read 2007), West Africa (Hawkes et al. 2006) and Japan (Hatase et al. 2002) suggests that there is more variation in life history strategies within even single populations than previously thought (Bolten 2003, 2007, Harrison \& Bjorndal 2006).

The coastal shelf of the Cuban archipelago has the second largest coral reef system in the Caribbean (3290 km²; Burke \& Maidens 2004), supporting a wide range of biodiversity. Five of the 6 species of sea turtles known to occur in the Caribbean have been documented in Cuban waters (loggerhead, green Chelonia mydas, hawksbill Eretmochelys imbricata, leatherback Dermochelys coriacea and olive ridley Lepidochelys olivacea; Carrillo \& Moncada 1998), of which the loggerhead is one of the most common. Most loggerhead turtles in Cuba are found on the islands and keys of the Canarreos Archipelago (e.g. Isla de la Juventud and San Felipe Keys; Moncada 2001, Ibarra et al. 2002, Nodarse et al. 2002) and in smaller numbers off the Guahanacabibes Peninsula (Ibarra et al. 2002). Data from fisheries captures in Cuban waters suggest that loggerhead turtles can be found at foraging and refuge sites in waters surrounding the island, and that they have been subject to direct harvest in the past (Mon- cada 1992, 2001, F. Moncada \& G. Nodarse unpubl. data). Direct harvest has now ceased due to the 2008 voluntary moratorium on sea turtle harvest in Cuba (Campbell et al. 2009), which should support the recovery of loggerhead turtle populations in other Caribbean nations, many of which are thought to be at remnant levels compared to the historic past (Bell et al. 2006, 2007).

In order to complement existing information with appropriate sea turtle conservation planning, it is important to understand loggerhead turtle movements both within Cuba and between Cuba and other nations. Notwithstanding, there are no published data describing home ranges, foraging areas or migratory routes for Cuban loggerhead turtles.

In the present study we provide the first comprehensive report of loggerhead turtle flipper tag recapture data for Cuba, including turtles tagged in Cuba and reported elsewhere, as well as turtles tagged elsewhere and reported in Cuba. We present data from the Cuban National Tagging Program (CNTP) with the aim of (1) enhancing current understanding of the movement patterns of loggerhead turtles in Cuban waters and throughout the Caribbean Sea and (2) providing data on distribution of, and distances travelled by, the tagged turtles between release and recapture.

\section{MATERIALS AND METHODS}

The Fisheries Research Center of Cuba initiated an annual turtle surveying and tagging program, the CNTP, in 1989. Turtles were tagged with metal flipper tags (Inconel style, National Band and Tag Company) on the trailing edge of the front flippers when they were either (1) encountered during nesting at Isla de la Juventud or (2) captured in Cuban waters as part of a CNTP project (northeast region: Nuevitas, Punta de Ganado, Las Tunas, Morrillo, Herradura, Cobarrubias and Palancon; southwest region: Isla de la Juventud; Fig. 1). All turtles in the CNTP program were measured following Bolten (1999), with curved carapace length (CCL) from notch to tip reported throughout, and were classified as adult or juvenile based on the presence of secondary sexual characteristics and carapace length. Flipper tag returns by turtle fishermen, unrelated to the CNTP survey, were also used in the present study.

Turtles that already carried flipper tags when captured were classified as recaptures. Source data for recaptured turtles were located from the CNTP program (1989-2002) and from other (non-Cuban) national and multinational tag databases (1959-2002) in order to ascertain when and where the turtle was originally tagged. Where possible, additional data 


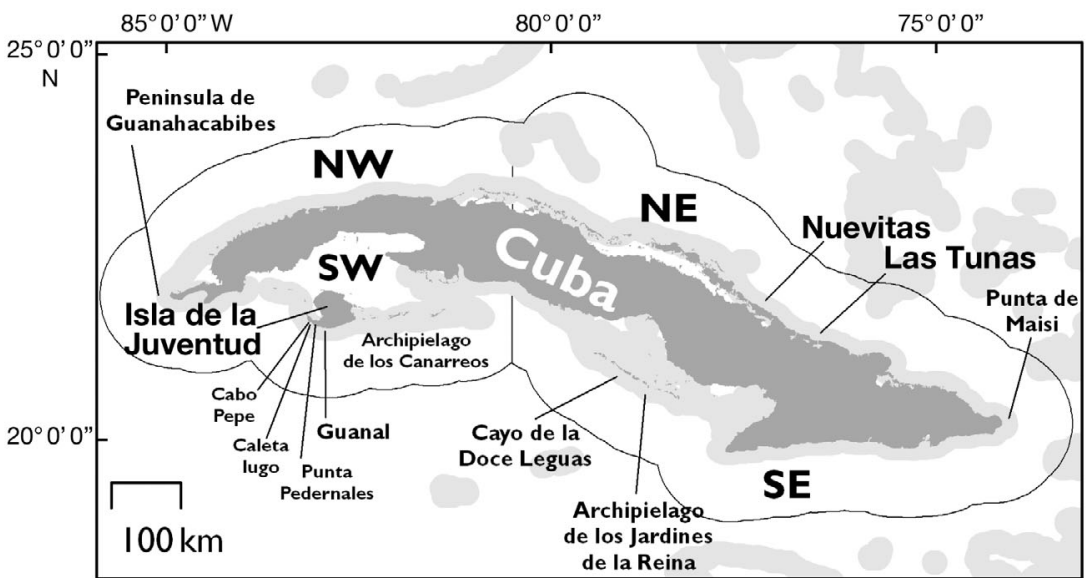

Fig. 1. Cuba, showing sites where loggerhead turtles were flipper-tagged. North coast: Nuevitas, Las Tunas; south coast: Isla de la Juventud. Black line shows extent of the Cuban Exclusive Economic Zone; grey shading shows coral reef locations (from Burke \& Maidens 2004)

describing CCL, gender and life stage were collected from the tagging programs.

Distance between release and recapture locations was calculated using MapSource software (version 3.02, Garmin), and minimum speed was calculated by dividing the distance travelled by the time between deployment and recapture. If turtles were at liberty for more than $1 \mathrm{yr}$ before recapture, speed was not calculated. Data were tested for normality and where they failed, non-parametric statistics were carried out in SigmaStat 3.1. Data were mapped in ArcGIS 9.2. Data are presented as means $\pm \mathrm{SD}$.

\section{RESULTS}

During the 14 yr tagging study conducted within Cuban waters, we tagged 126 adult female loggerhead turtles nesting at Isla de la Juventud (mean $\mathrm{CCL}=98.5 \pm 10.3 \mathrm{~cm}$, range $=83.0$ to $120.0 \mathrm{~cm}$, sizes not available for 26 tagged turtles) and 84 adult and juvenile loggerhead turtles captured in-water $($ mean $\mathrm{CCL}=93.8 \pm 9.6 \mathrm{~cm}$, range $=63.0$ to $107.0 \mathrm{~cm}$ ) (Fig. 2). We recaptured 14 of the turtles that we had tagged during in-water ( $\mathrm{n}=8$ turtles) and nesting beach surveys $(n=7)$, and a further 50 turtles from non-Cuban projects were recaptured by fishermen in Cuban waters (detailed below; Fig. 3a,b). One individual with Cuban flipper tags was reported from Nicaraguan waters. Due to the scale of movement involved, we deal with these recaptures separately.

\section{Loggerhead turtles tagged in Cuban waters}

The majority (14) of the 15 turtles tagged in Cuba were recaptured inside the Cuban shelf (Fig. 3a) between 2 and $1037 \mathrm{~d}$ after tagging $($ mean $=322.8 \pm 411.6 \mathrm{~d}$, Table 1$)$. Adults $(\mathrm{n}=13)$ were recaptured after longer periods at liberty than juveniles $(\mathrm{n}=$ 2 ; mean $=436.1 \pm 541 \mathrm{~d}$ versus $15 \pm 14.1 \mathrm{~d}$ ), and generally further away (mean distance between tagging and recapture sites for adults and juveniles $=370.6 \pm 566$ versus $36.5 \pm 4.9 \mathrm{~km}$, respectively). Minimum distances between tagging and recapture sites for juvenile and adult turtles tagged at Nuevitas and Las Tunas fishing grounds ranged from 18 to $1180 \mathrm{~km}$ (mean $=429.6$ $\pm 501.8 \mathrm{~km})$ and were equivalent to mean travel speeds of $13.2 \pm 5.8 \mathrm{~km} \mathrm{~d}^{-1}$ (range $=8$ to $\left.20.30 \mathrm{~km} \mathrm{~d}^{-1}\right)$. Nesting females had moved $0.5 \pm 0.1 \mathrm{~km}$ $\mathrm{d}^{-1}$ (range 0.3 to $0.6 \mathrm{~km} \mathrm{~d}^{-1}$ ).

There appeared to be little movement of turtles between the northern and southern coasts of Cuba. Seven turtles tagged originally on the north coast were recaptured later, at Pinar del Rio $(\mathrm{n}=2)$ or Nuevitas and Las Tunas $(\mathrm{n}=4)$ on the north coast, but also Isla de la Juventud $(n=1)$ on the south coast. Seven turtles tagged originally on the south coast were recaptured, all on the south coast-at Cabo Pepe $(\mathrm{n}=3)$, Punta Pedernales $(n=3)$ and Caleta Lugo $(n=1)$. Six south coast recaptures were of nesting females from Isla de la Juventud. Adult turtles, originally tagged while nesting, were recaptured in Cuban waters around 29 June (median date, range $=19$ March to 12 August), coinciding with the nesting season.

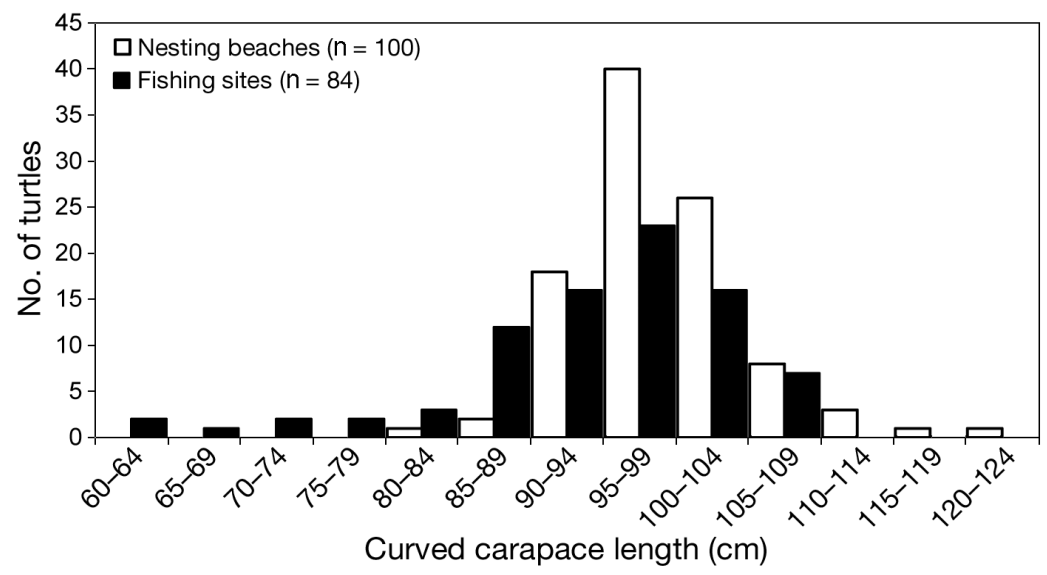

Fig. 2. Caretta caretta. Size distribution of loggerhead turtles used in the Cuban tag-recapture studies. Sizes at tagging of turtles caught at fishing areas are in black $(\mathrm{n}=100)$, and those tagged at the Guanal nesting beach (nesting females, $\mathrm{n}=84$ ) are in white 

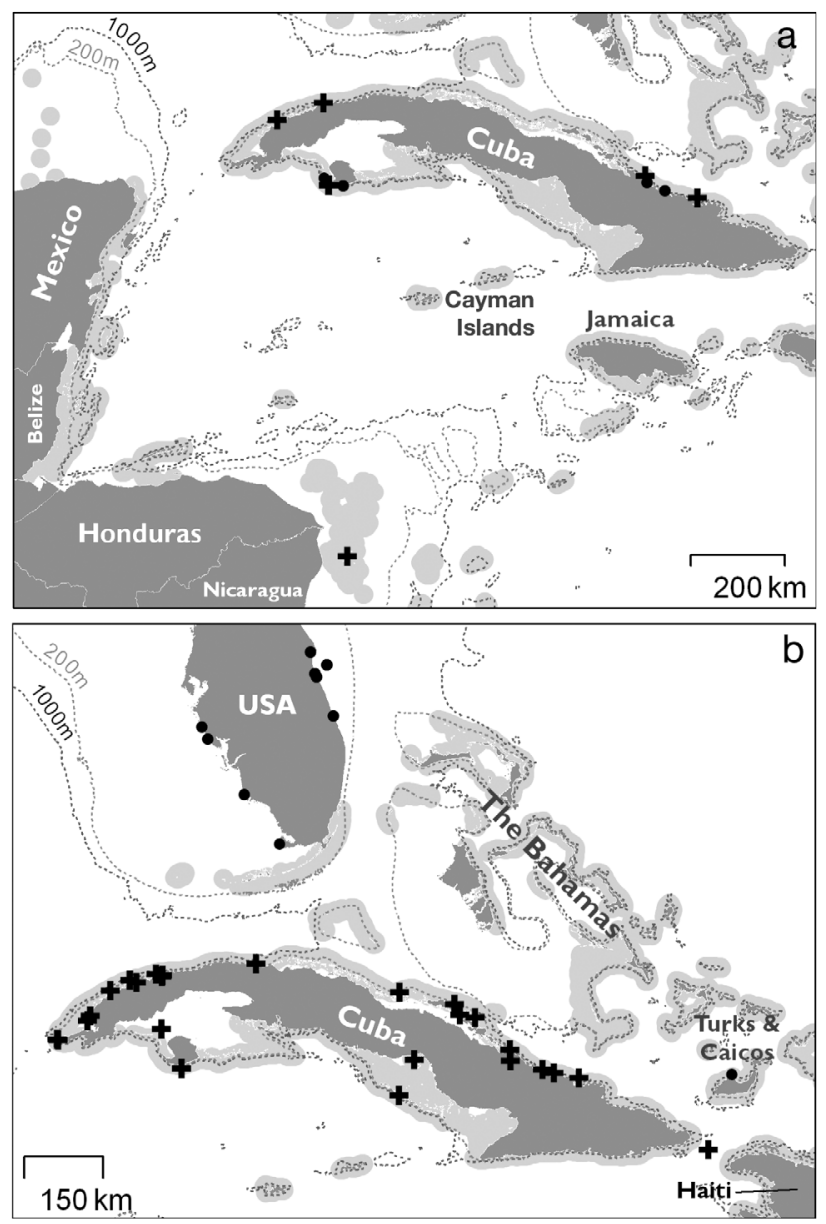

Fig. 3. Deployment $(\bullet)$ and recaptures (+) of flipper-tagged loggerhead turtles from (a) the Cuban National Tagging Program and (b) other projects. Light grey shading shows the location of coral reefs (data from the Reefs at Risk project,

Burke \& Maidens 2004). Note the different scales
However, turtles did appear to move longitudinally along the north or south coasts. One turtle tagged during in-water surveys in Punta de Ganado (Nuevitas) travelled eastwards (and was recaptured in-water) while another turtle (also tagged during in-water surveys) headed west towards Buenavista (north of Pinar del Rio). Three other turtles tagged in Cobarrubias (Las Tunas) swam east towards Punta de Ganado. In-water recaptures of turtles tagged during in-water surveys from the SW region suggested movement in both directions, both with and against prevailing marine currents. One male loggerhead turtle, tagged during in-water surveys, travelled east toward Guanal Beach against prevailing currents at the beginning of the reproductive season and was recaptured in-water in a subsequent survey, while 2 females, tagged while nesting, travelled westward with surface currents and were recaptured in-water in subsequent surveys 34 and $61 \mathrm{~d}$ later, respectively. These movements may represent inter-nesting, as these turtles were recaptured close to the nesting beach $(<32 \mathrm{~km})$ within a period of 34 to $68 \mathrm{~d}$, and showed speeds much slower $(0.3$ to $0.6 \mathrm{~km}$ $\mathrm{d}^{-1}$ ) than others. A further 3 females were recaptured in-water 808, 1006 and 1009 d, respectively, after tagging at the nesting beach, possibly indicating an entire remigration period spent away from Cuban waters.

\section{Loggerhead turtles tagged outside Cuba}

The majority (42) of the 50 loggerhead turtles recaptured in Cuban waters from foreign tagging programs were originally tagged in Florida, USA (originally tagged while nesting at a variety of Florida beaches: Cape Canaveral, Keewaydin Island, Melbourne Beach,

Table 1. Caretta caretta. Loggerhead turtles recaptured from the Cuban National Tagging Program. Turtle tag numbers are shown after deployment dates. CCL: curved carapace length, measured from notch to tip

\begin{tabular}{|c|c|c|c|c|c|c|}
\hline Release date & Release location & CCL & Life stage & $\begin{array}{c}\text { Recapture } \\
\text { date }\end{array}$ & Recapture location & $\begin{array}{l}\text { Duration } \\
\text { (d) }\end{array}$ \\
\hline 04 May 89 (CU 0501) & Cobarrubias, Las Tunas & 90 & Juvenile & 29 May 89 & P. Ganado, Nuevitas & 25 \\
\hline 28 Jun 91 (C 3110) & Cobarrubias, Las Tunas & 86 & Juvenile & 30 Jun 91 & P. Ganado, Nuevitas & 2 \\
\hline 19 May 89 (CU 0516) & Cobarrubias, Las Tunas & 94 & Adult female & 24 May 91 & P. Ganado, Nuevitas & 5 \\
\hline 25 May 89 (CU 0329) & P. Ganado, Nuevitas & 93 & Adult female & 12 Aug 89 & Buena Vista, P. del Río & 78 \\
\hline 10 Jun 90 (CU0349) & P. Ganado, Nuevitas & 98 & Adult female & 12 Apr 92 & Inés de Soto, P. del Río & 1037 \\
\hline 07 May 91 (CU 0050) & Guanal Beach, I. Juventud & 95 & Adult female & 02 Aug 95 & White Reef, Miskitos & 1489 \\
\hline 18 May 92 (C 4413) & Guanal Beach, I. Juventud & 98 & Adult female & 25 Jul 92 & Caleta Lugo, I. Juventud & 68 \\
\hline 29 May 92 (C 3381) & P. Ganado, Nuevitas & 101 & Adult female & 22 Jul 92 & La Papaya, I. Juventud & 58 \\
\hline 18 Jun 92 (C 4441) & Guanal Beach, I. Juventud & 94 & Adult female & 22 Jul 92 & Cabo Pepe, I. Juventud & 34 \\
\hline 02 Jul 93 (C 4149) & Guanal Beach, I. Juventud & 110 & Adult female & 20 Apr 95 & Pedernales, I. Juventud & 808 \\
\hline 05 Jun 96 (C 4278) & Guanal Beach, I. Juventud & 100 & Adult female & 29 Apr 99 & Pedernales, I. Juventud & 1006 \\
\hline 05 Jun 96 (C 4426) & Guanal Beach, I. Juventud & 98 & Adult female & 06 Aug 96 & Cabo Pepe, I. Juventud & 61 \\
\hline 16 Jun 96 (C 4280) & Guanal Beach, I. Juventud & 99 & Adult female & 30 Apr 99 & Pedernales, I. Juventud & 1009 \\
\hline 05 Jun 91 (C 3111) & P. Ganado, Nuevitas & 100 & Adult male & 07 Jun 91 & Morrillo, Las Tunas & 2 \\
\hline 01 Mar 00 (C 4912) & Pedernales, I. Juventud & 102 & Adult male & 19 Mar 00 & Cabo Pepe, I. Juventud & 15 \\
\hline
\end{tabular}


Casey Key, Melbourne Beach and Hutchinson Island; Table 2). A further 5 loggerhead turtles were originally tagged at nesting beaches at Quintana Roo, Mexico, and 1 each in The Bahamas, Canary Islands and coastal Spain. The majority of recaptures of foreign tagged turtles (84\%) were along the north coast of Cuba, and over $50 \%$ of turtles were recaptured along the northwestern coastal shelf (Fig. 3). Some turtles originally tagged in either Florida or Mexico were recaptured along the south coast of Cuba (Fig. 3), indicating travel of a minimum of approximately $1400 \mathrm{~km}$. Two turtles tagged in the Bahamas and Spain were recaptured on the NE coast (near Punta de Maisi and Nuevitas, respectively), and the turtle from the Canary Islands was recovered on the southwestern coast of Cuba. One loggerhead turtle originally tagged in Spain was a juvenile of $68 \mathrm{~cm}$ (CCL, notch to tip).

\section{Loggerheads tagged in Cuba and recaptured elsewhere}

One loggerhead turtle from the CNTP was recaptured in international waters, near White Reef, Nicaragua.

\section{DISCUSSION}

\section{Life stages present in Cuba}

The results of the tagging program recaptures reported between 1989 and 2002 suggest that loggerhead turtles from a range of life stages occupy the Cuban coastal shelf, both on the north and south coasts. This finding is supported by traditional fisheries catches in Cuban waters (Carrillo et al. 1998, F. Moncada \& G. Nodarse unpubl. data), which described captures of both juvenile and adult turtles, some larger than the biggest turtle recaptured in the present study. The Cuban fishery historically also caught green and hawksbill turtles of varying sizes, suggesting that the capture equipment used to catch sea turtles is not selective for a specific size or species, and that capture data are therefore comparable with the present study. Tagging of nesting females suggests that Cuban loggerhead turtles (98.5 cm CCL, mean value) are larger than Mediterranean conspecifics $(73.6 \mathrm{~cm}$; Broderick et al. 2003), but similar in size to those reported from the Pacific and Atlantic USA (92.5 and $99.2 \mathrm{~cm}$, respectively; Ehrhart et al. 2003). Size composition has been studied for sea turtles captured in Cuban waters and the results indicate that this area is suitable and utilized by different life stages for several different species. Indeed, while the size range for loggerhead turtles in the present study (Fig. 2) is similar to the range found for females at Cuban nesting sites, in our previous work on green turtles (Moncada et al. 2006) the size classes (30 to $129 \mathrm{~cm}$ CCL) were instead consistent with a predominantly juvenile life stage.

\section{Turtles tagged in Cuba and their movements}

In the present study, 1 adult turtle was recaptured in Nicaragua, probably foraging in the Miskito Cays, an area which contains adequate reef and is a known foraging area for other species of sea turtles. Blumenthal et al. (2006) satellite-tracked 3 nesting loggerhead turtles from the Cayman Islands, just south of Cuba, and found that all 3 travelled to Nicaraguan waters to forage. However, limited movement restricted to Cuban national waters was recorded for the remaining nesting turtles that were recaptured in the course of the present study, to the extent that the majority of turtles were recaptured on the same coast on which they were originally tagged. The size of the Cuban coral reef (the second largest in the Caribbean by nation; Burke \& Maidens 2004) suggests that there should be ample suitable foraging habitat containing prey species known to be consumed by loggerhead turtles (Bjorndal 1985, Dodd 1988). Loggerhead turtles have a relatively broad diet (Bjorndal 2003) and are not thought to be obligate reef dwellers. In addition, long-term recaptures may represent gravid females returning to Cuban waters to nest, since they were typically reencountered near the nesting season. Given that

Table 2. Caretta caretta. Summary of loggerhead turtles recaptured from other tagging projects. Unk.: recapture location unknown

\begin{tabular}{|c|c|c|c|c|c|c|c|c|}
\hline \multirow[t]{2}{*}{ Tagging location } & \multirow[t]{2}{*}{ Life stage } & \multicolumn{5}{|c|}{ Recaptures along the Cuban shelf } & \multirow[t]{2}{*}{ Total } & \multirow[t]{2}{*}{ Recaptures (\%) } \\
\hline & & NW & $\mathrm{NE}$ & SW & $\mathrm{SE}$ & Unk. & & \\
\hline Florida & Adult & 23 & 15 & 2 & 2 & 0 & 42 & 84 \\
\hline Mexico & Adult female & 2 & 0 & 1 & 0 & 2 & 5 & 10 \\
\hline Spain \& Canary Islands & Juvenile & 0 & 1 & 1 & 0 & 0 & 2 & 4 \\
\hline Bahamas & Juvenile & 0 & 1 & 0 & 0 & 0 & 1 & 2 \\
\hline Total & & 25 & 17 & 4 & 2 & 2 & 50 & 100 \\
\hline
\end{tabular}


adults do not appear to be travelling further away, yet were recaptured less frequently in the present study, some aspect of their behaviour (e.g. diving depth) likely affected recapture rate.

\section{Turtles tagged outside Cuba and their movements}

Recaptures of loggerheads tagged in other national and multinational projects suggest that Cuba hosts foraging habitat for some large juvenile and adult loggerhead turtles from other countries. The majority of recaptured loggerhead turtles were originally tagged on nesting beaches in Florida (as well as The Bahamas, Canary Islands, Mexico and Spain) and were found along the north coast of Cuba. These results are broadly similar to those of Moncada et al. (2006), where green turtles from the USA and Mexico were recaptured in Cuban waters, but differ in that the majority of our (albeit small sample size) recaptured turtles were recaptured in Cuban waters (25 of 41 recaptured green turtles were recaptured outside of Cuban waters).

The timing of original tagging (May to July) and subsequent recapture (September to November) of loggerhead turtles in the present study suggests that some of the foraging habitats for Florida nesting loggerhead turtles (Schroeder et al. 2003) are located in Cuba, and that they potentially remain there for the duration of the remigration interval until the next nesting year (Meylan et al. 1983, Ehrhart et al. 2003, B. Schroeder unpubl. data). However, there is more reef habitat on the south coast of Cuba than the north coast (Burke \& Maidens 2004), which suggests that, perhaps for nesting females, proximity to nesting beach rather than absolute habitat availability may be important in determining where turtles forage in Cuba. Mexican loggerhead turtles from the regionally significant Quintana Roo subpopulation (Encalada et al. 1998) that were recaptured on the western Cuban shelf (both on northern and southern coasts) also migrated eastwards from nesting beaches in Mexico to forage on the Cuban reef for the duration of their remigration interval.

Decreases in the Florida loggerhead turtle southern subpopulation over 18 yr (Encalada et al. 1998, Witherington et al. 2009) have been hypothesised to reflect direct take of loggerhead turtles in countries including The Bahamas and Cuba, but the 2008 moratorium in Cuba, if enforced, will result in significantly reduced directed harvest of loggerheads in Cuban waters. Prior to the present moratorium, and from 1994 onwards, the Cuban turtle fishery was closed at all but 2 traditional harvest sites (Isla de la Juventud and Nuevitas; Carrillo et al. 1999), capturing approximately $5 \mathrm{t}$ of turtles of varying sizes and age classes between them per annum. It is not known to what extent these 2 areas are used for foraging by loggerhead turtles, and we recommend that further research be carried out using genetic techniques (Bowen et al. 1996) to elucidate the relative contribution of foreign loggerhead turtle stocks to Cuban foraging grounds. Nonetheless, with fisheries bycatch a particular threat to sea turtles (Lewison et al. 2004), there are likely additional factors that have contributed to the observed Florida population decline.

The 2 juvenile turtles originally tagged in the Canary Islands and Spain must have crossed the Atlantic Ocean, probably as part of a trans-oceanic developmental migration (Bolten 2003, Eckert et al. 2008). These records are similar to the tag return reported for a large juvenile loggerhead turtle (84 cm straight carapace length) tagged and released in the waters of the Canary Islands and recaptured 5 mo later off the south coast of Isla de la Juventud (Bolten et al. 1992). The minimum distance travelled by this turtle was approximately $6900 \mathrm{~km}$, and the minimum rate of travel was about $45 \mathrm{~km} \mathrm{~d}^{-1}$. Accepted life history models for loggerhead turtles (e.g. Laurent et al. 1998, Bolten 2003, Camiñas 2005, Carreras et al. 2006) suggest that hatchling turtles from the western Atlantic leave their nesting beaches, become passively entrained in oceanic currents and are likely carried to juvenile developmental grounds in the eastern Atlantic, most notably at the Azores and Canary Islands. They spend approximately 7 to $12 \mathrm{yr}$ in these developmental areas (Bjorndal et al. 2003) before returning to the western Atlantic to recruit to coastal foraging grounds (but see McClellan \& Read 2007). We therefore consider that these trans-Atlantic recaptures were turtles returning to their natal region in the western Atlantic. The turtle recaptured in Cuba from Spain (tagged 3 yr earlier in Balearic Islands waters) is the first sign of a return from the Mediterranean (a recognised feeding area for loggerhead turtles) to the Caribbean. The turtle recaptured from a Bahamian tagging project (based on printed return data on the tag) should be viewed with caution as it was a 'head-started' individual and was smaller at recapture than all other individuals than we encountered in the present study (but see Bell et al. 2005). This loggerhead turtle was raised for $3 \mathrm{yr}$ at the Seafloor Aquarium in Nassau, released on Great Inagua Island in September 1982 and recaptured in Cuba in January 1991.

Of all turtles tagged in the present study, approximately 3 times as many loggerhead turtles were recaptured on the north coast compared to the south coast of Cuba, and these turtles are of mixed origins, coming from the eastern Atlantic, wider Caribbean or from Cuba itself. Although the migratory routes taken for turtles to reach Cuban foraging grounds are as yet unknown, they likely involve fairly direct crossings with occasional interaction with major surface currents 
(tracking studies reviewed in Godley et al. 2008). The data in the present study highlight the importance of the Cuban shelf to loggerhead turtles from multiple origins and the abundance, distribution and species of turtles using Cuban reef habitats for foraging. In particular, the abundance and structure of in-water populations of turtles foraging at traditional turtle harvest sites warrants further investigation. These results also underscore the value of long-term tagging programs as a complement to other spatial tools such as satellite tracking.

Acknowledgements. Information on recaptured tags was generously provided by P. Eliazar, V. Guzmán, C. Lagueux, J. Ottenwalder, A. Rodriguez, A. Meneses and C. Scantlebury. Thanks to all researchers and specialists who sent us the information on turtles recaptured in Cuba and other nations. Completion of this paper was made possible by a doctoral scholarship to F.M. by CONACYT (México), the Centro de Investigaciones Biológicas del Noroeste (México) and the Centro de Investigaciones Pesqueras (Cuba). We thank J. Seminoff and S. Gardner for comments that improved earlier versions of this manuscript. We gratefully acknowledge the University of Central Florida, NMFS Southeast Fisheries Center, Bahamas Turtle Project, Archie Carr Center for Sea Turtle Research (University of Florida), Spanish Oceanographic Institute (IEO) and other institutions that provided information for this paper. Thanks also to all fishermen and colleagues who collaborated with our tagging programs. L.A.H. was supported by a MacArthur Foundation grant to the WWF in Belize and thanks Dr. C. Drews (WWF Latin America) for kind advice and help. The Reefs at Risk in the Caribbean database is comprised of data from the Millennium Coral Reef Mapping project from the University of South Florida, NOAA benthic habitats of Puerto Rico and the US Virgin Islands project, the Coastal Zone Management Institute of Belize and the Coral Reef Maps UNEP WCMC project. This manuscript was considerably improved by the comments of 3 anonymous reviewers and T. Tucker.

\section{LITERATURE CITED}

Bell R, Richardson JI (1978) An analysis of tag recoveries from loggerhead sea turtles (Caretta caretta) nesting on Little Cumberland Island, Georgia. Fla Mar Res Publ 33:20-24

Bell CD, Parsons J, Austin TJ, Broderick AC, Ebanks-Petrie G, Godley BJ (2005) Some of them came home: the Cayman Turtle Farm headstarting project for the green turtle Chelonia mydas. Oryx 39:137-148

Bell CD, Blumenthal JM, Austin TJ, Solomon JL, EbanksPetrie G, Broderick AC, Godley BJ (2006) Traditional Caymanian fishery may impede local marine turtle population recovery. Endang Species Res 2:63-69

Bell CD, Solomon JL, Blumenthal JM, Austin TJ, EbanksPetrie G, Broderick AC, Godley BJ (2007) Monitoring and conservation of critically reduced marine turtle nesting populations: lessons from the Cayman Islands. Anim Conserv 10:39-47

Bjorndal KA (1985) Nutritional ecology of sea turtles. Copeia 1985:736-751

Bjorndal KA (2003) Roles of loggerhead sea turtles in marine ecosystems. In: Bolten AB, Witherington BE (eds) Loggerhead sea turtles. Smithsonian, Washington, DC, p 235-254
Bjorndal KA, Bolten AB, Martins HR (2000) Somatic growth model of juvenile loggerhead sea turtles Caretta caretta: duration of pelagic stage. Mar Ecol Prog Ser 202:265-272

Bjorndal KA, Bolten AB, Dellinger T, Delgado C, Martins HR (2003) Compensatory growth in oceanic loggerhead sea turtles: response to a stochastic environment. Ecology 84: 1237-1249

Blumenthal JM, Solomon JL, Bell CD, Austin TJ and others (2006) Satellite tracking highlights the need for international cooperation in marine turtle management. Endang Species Res 2:51-61

Bolten AB (1999) Techniques for measuring sea turtles. In: Eckert KL, Bjorndal KA, Abreu-Grobois FA, Donnelly M (eds) Research and management techniques for the conservation of sea turtles. IUCN/SSC Marine Turtle Specialist Group Publication No. 4, Washington, DC, p 110-114

Bolten AB (2003) Active swimmers - passive drifters: the oceanic juvenile stage of loggerheads in the Atlantic system. In: Bolten AB, Witherington BE (eds) Loggerhead sea turtles. Smithsonian, Washington, DC, p 63-78

Bolten AB (2007) The natural history and modern challenges of the North Atlantic loggerhead. In: Mast RB, Bailey LM, Hutchinson BJ (eds) State of the world's sea turtles report, Vol II. SWOT, Arlington, VA, p 15. Available at http://seaturtlestatus.org/pdf/r2_naturalhistory.pdf

Bolten AB, Santana JC, Bjorndal KA (1992) Trans-Atlantic crossing by a loggerhead turtle. Mar Turtle Newsl 59:7-8

Bolten AB, Bjorndal KA, Martins HR, Dellinger T, Biscoito MJ, Encalada SE, Bowen BW (1998) Transatlantic developmental migrations of loggerhead sea turtles demonstrated by mtDNA sequence analysis. Ecol Appl 8:1-7

> Bowen BW, Karl SA (2007) Population genetics and phylogeography of sea turtles. Mol Ecol 16:4886-4907

> Bowen BW, Bass AL, Garcia-Rodriguez A, Diez CE and others (1996) Origin of hawksbill turtles in a Caribbean feeding area as indicated by genetic markers. Ecol Appl 6:566-572

Bowen BW, Bass AL, Chow SM, Bostrom M and others (2004) Natal homing in juvenile loggerhead turtles (Caretta caretta). Mol Ecol 13:3797-3808

Bowen BW, Bass AL, Soares L, Toonen RJ (2005) Conservation implications of complex population structure: lessons from the loggerhead turtle (Caretta caretta). Mol Ecol 14: 2389-2402

Broderick AC, Glen F, Godley BJ, Hays GC (2003) Variation in reproductive output of marine turtles. J Exp Mar Biol Ecol 288:95-109

Burke L, Maidens J (2004) Reefs at risk in the Caribbean. World Resources Institute, Washington, DC. Available at www.wri.org/publication/reefs-risk-caribbean

Camiñas JA (2005) Biología y comportamiento migratorio de la tortuga boba (Caretta caretta Linnaeus, 1758) en el Mediterráneo occidental. PhD thesis, Universidad Complutense de Madrid

Campbell LM, Silver JJ, Gray NJ, Ranger S and others (2009) Co-management of sea turtle fisheries: biogeography versus geopolitics. Mar Policy 33:137-145

Carr AF (1986) Rips, FADs, and little loggerheads. Bioscience $36: 92-100$

Carreras C, Pont S, Maffucci F, Pascual M and others (2006) Genetic structuring of immature loggerhead sea turtles (Caretta caretta) in the Mediterranean Sea reflects water circulation patterns. Mar Biol 149:1269-1279

Carrillo E, Moncada F (1998) Annex 1. Cuban sea turtles. Rev Cub Investig Pesq 22:59-60

Carrillo E, Moncada F, Elizalde S, Nodarse G, Perez C, Rodriguez AM (1998) Annex 4. Historical harvest, trade and sampling data. Rev Cub Investig Pesq 22:75-88 
Carrillo E, Webb G, Manolis C (1999) Hawksbill turtles Eretmochelys imbricata in Cuba: an assessment to the historical harvest and its impact. Chelonian Conserv Biol 3: 264-280

Casale P, Mazaris AD, Freggi D, Vallini C, Argano R (2009) Growth rates and age at adult size of loggerhead sea turtles (Caretta caretta) in the Mediterranean Sea, estimated through capture-mark-recapture records. Sci Mar 73: 589-595

Dodd CK Jr (1988) Synopsis of the biological data on the loggerhead sea turtle Caretta caretta (Linnaeus 1758). US Fish Wildl Serv Biol Rep 88(14)

Dow W, Eckert K, Palmer M, Kramer P (2007) An atlas of sea turtle nesting habitat for the wider Caribbean region. WIDECAST Technical Report No. 6. The Wider Caribbean Sea Turtle Conservation Network and The Nature Conservancy, Beaufort, NC. Available at http://seamap.env. duke.edu/widecast

Eckert SA, Moore JE, Dunn DC, van Buiten RS, Eckert KL, Halpin PN (2008) Modelling loggerhead turtle movement in the Mediterranean: importance of body size and oceanography. Ecol Appl 18:290-308

Ehrhart LM, Bagley DA, Redfoot WE (2003) Loggerhead turtles in the Atlantic Ocean: geographic distribution, abundance and population status. In: Bolten $A B$, Witherington $\mathrm{BE}$ (eds) Loggerhead sea turtles. Smithsonian, Washington, DC, p 157-174

Encalada SE, Bjorndal KA, Bolten AB, Zurita JC and others (1998) Population structure of loggerhead turtle (Caretta caretta) nesting colonies in the Atlantic and Mediterranean as inferred from mitochondrial DNA control region sequences. Mar Biol 130:567-575

Godley BJ, Blumenthal JM, Broderick AC, Coyne MS, Godfrey MH, Hawkes LA, Witt MJ (2008) Satellite tracking of sea turtles: Where have we been and where do we go next? Endang Species Res 4:3-22

Harrison AL, Bjorndal KA (2006) Connectivity and wideranging species in the ocean. Crooks KR, Sanjayan MA (eds) Connectivity conservation. Cambridge University Press, Cambridge, p 213-232

- Hatase H, Takai N, Matsuzawa Y, Sakamoto W and others (2002) Size-related differences in feeding habitat use of adult female loggerhead turtles Caretta caretta around Japan determined by stable isotope analyses and satellite telemetry. Mar Ecol Prog Ser 233:273-281

- Hawkes LA, Broderick AC, Coyne MS, Godfrey MH and others (2006) Phenotypically linked dichotomy in sea turtle foraging strategies requires multiple conservation approaches. Curr Biol 16:990-995

Hopkins-Murphy SR, Owens DW, Murphy TM (2003) Ecology of immature loggerheads on foraging grounds and adults in internesting habitat in the eastern United States. In: Bolten AB, Witherington BE (eds) Loggerhead sea turtles. Smithsonian, Washington, DC, p 79-92

Ibarra ME, Díaz-Fernández R, Konnorov AN, Azanza J, Valdés JA, Espinosa G, Roberto JP (2002) Project update: university project for the study and conservation of Cuban sea turtles-completion of year 3. Mar Turtle Newsl 95:18-20

IUCN (International Union for Conservation of Nature and Natural Resources) (2008) Red List of threatened species. Available at www.iucnredlist.org

Editorial responsibility: Mark Hamann,

Townsville, Queensland, Australia
Laurent L, Casale P, Bradai MN, Godley BJ and others (1998) Molecular resolution of marine turtle stock composition in fishery bycatch: a case study in the Mediterranean. Mol Ecol 7:1529-1542

Lewison RL, Freeman SA, Crowder LB (2004) Quantifying the effects of fisheries on threatened species: the impact of pelagic longlines on loggerhead and leatherback sea turtles. Ecol Lett 7:221-231

> Limpus CJ, Miller JD, Paramenter CJ, Reimer D, McLachlan N, Webb R (1992) Migration of green (Chelonia mydas) and loggerhead (Caretta caretta) turtles to and from eastern Australian rookeries. Wildl Res 19:347-358

> McClellan CM, Read AJ (2007) Complexity and variation in loggerhead sea turtle life history. Biol Lett 3:592-594

Meylan AB, Bjorndal KA, Turner BJ (1983) Sea turtles nesting at Melbourne Beach, Florida, II. Post-nesting movements of Caretta caretta. Biol Conserv 26:79-90

Moncada F (1992) Migraciones de las tortugas marinas en la plataforma cubana. Resultados preliminares. Rev Cub Investig Pesq 18:12-15

Moncada F (2001) Status and distribution of the loggerhead turtle, Caretta caretta, in the wider Caribbean region. In: Eckert KL, Abreu Grobois FA (eds) Marine turtle conservation in the wider Caribbean region: a dialogue for effective regional management. WIDECAST, IUCN/SSC/ MTSG, WWF and the UNEP Caribbean Environment Programme, Santo Domingo, p 108-109

Moncada F, Abreu-Grobois A, Muhlia A, Bell C and others (2006) Movement patterns of green turtle (Chelonia mydas) in Cuba and adjacent Caribbean waters inferred from flipper tag recaptures. J Herpetol 40:22-34

Nodarse G, Moncada F, Meneses A Rodríguez C (2002) Monitoring of loggerhead turtle (Caretta caretta) nesting on the south coast of the Isla de la Juventud, Cuba. In: Mosier A, Foley A, Brost B (eds) Proc 20th Annu Sea Turtle Symp. NOAA Tech Memo NMFS-SEFSC-477:98-100

Rankin-Baransky K, Williams CJ, Bass AL, Bowen BW, Spotila JR (2001) Origin of loggerhead turtles stranded in the northeastern United States as determined by mitochondrial DNA analysis. J Herpetol 35:638-646

Reich KJ, Bjorndal KA, Bolten AB (2007) The 'lost years' of green turtles: using stable isotopes to study cryptic lifestages. Biol Lett 3:712-714

Revelles M, Camiñas JA, Cardona L, Parga M and others (2008) Tagging reveals limited exchange of immature loggerhead sea turtles (Caretta caretta) between regions in the western Mediterranean. Sci Mar 72:511-518

Schroeder BA, Foley AM, Bagley DA (2003) Nesting patterns, reproductive migrations, and adult foraging areas of loggerhead turtles. In: Bolten AB, Witherington BE (eds) Loggerhead sea turtles. Smithsonian, Washington, DC, p 114-124

Troëng S, Dutton PH, Evans D (2005) Migration of hawksbill turtles Eretmochelys imbricata from Tortuguero, Costa Rica. Ecography 28:394-402

Witherington B, Kubilis P, Brost B, Meylan A (2009) Decreasing annual nest counts in a globally important loggerhead sea turtle population. Ecol Appl 19:30-54

Zbinden J, Aebischer A, Margaritoulis D, Arlettaz R (2007) Important areas at sea for loggerhead sea turtles in the Mediterranean Sea: satellite tracking corroborates findings from potentially biased sources. Mar Biol 453:899-906

Submitted: June 19, 2009; Accepted: October 21, 2009

Proofs received from author(s): January 18, 2010 